\title{
Lo maravilloso y la ficcionalización del sujeto en Tomás Harris*
}

\author{
Dr. Ricardo Ferrada Alarcón**
}

\section{Resumen:}

Este artículo refiere al libro Crónicas maravillosas del escritor chileno Tomás Harris, donde intentamos explorar aspectos de su composición que lo vinculan al tono épico de la poesía.

Nos preocupa en específico en las Crónicas la actualización de una "voz poética", en el cruce de los tiempos y de sus referentes culturales, luego el traslado imaginario de un sujeto que devela rupturas y ensambles de una realidad que se recibe como extraña y situada multívocamente; esto se plasma en un (des)encuentro con la historia, una voz que desdobla el texto y su propia identidad, operando en sus cambios de perspectiva y de tiempos la ficcionalización del personaje poético. Nuestro desarrollo es un intento de "transducción", que se sostiene en presentar lecturas previas sobre Harris, los rasgos que constituyen su crónica maravillosa y el efecto que genera su poética de ficcionalización, al sobrearticular los tiempos y el discurso con un sujeto que se mueve en los espacios de lenguaje.

Palabras clave: épica, crónica, maravilloso, voz poética, transducción, poética de ficcionalización, desdoblamiento.

\section{Abstract:}

This article refers to the book Crónicas maravillosas of the chilean writer Thomas Harris, where we try to explore aspects of its composition that linking it with the tone of epic poetry.

In particular, we are interested in the Crónicas for the activation of a "poetic voice" at the cross of the times and their cultural references, then the imaginary trip of a subject who reveals breaks and couplings of a reality that is received as strange and multifocusly located; this is reflected in the (un)meeting with the history, a voice that unfold the text and his own identity, operating in his perspective changes and times the fictitiousness of the poetic character.

Our develop is an attempt to "transduction", which is hold in some previus lectures of Harris, the tracks that constitute its crónica maravillosa and the effect that generates its fictionality poetics, when the overarticulation times and the speech, with a subject moving in the languajes spaces.

Key words: epic, chronic, wonderful, poetics voice, transduction, fictionality poetics, unfolding.

* Parte de este trabajo fue presentada el año 2006 en el "Primer Congreso de Poesía Chilena del Siglo XX", organizado por el Departamento de Literatura de la Facultad de Filosofía y Humanidades, U. de Chile.

* Académico Universidad Católica Silva Henríquez. Departamento de Humanidades. jferrada@ucsh.cl 


\section{Introducción}

La producción literaria desarrollada a partir de los (des)bordes de la historia, constituye una constante fundacional de un género, esto es, la épica. Mediante ella se han instaurado líneas de significación que logran identificar paisajes humanos y geográficos, gestas heroicas, actos de nobleza y búsquedas legendarias, idiomas que germinan. De allí la radicalidad de las construcciones poéticas que refieren a la experiencia colectiva, pero cuyas marcas intentan mostrar la actitud de los sujetos frente a ella, en la medida que su formulación nos pone frente a dimensiones que tensionan el "lado interior de la realidad", sus componentes de vida, festividades, pasiones, dudas, héroes emblemáticos, luchas contra lo imposible, episodios que expresan la sensibilidad de una cultura.

Se sabe que en la poesía contemporánea ese modelo inicial ancla en variadas estéticas en que opera el "tono" épico, donde no es extraño que el poeta asuma distancias en su estrategia creativa, mostrada en un proceso en que se oculta o transforma la materialidad del sujeto lírico ante la experiencia de un mundo que lo excede. Esto se evidencia en un espacio poético que se ficcionaliza para hacer entrar variadas y posibles facturas, donde subvertir los códigos convencionales de lo que estimamos real se convierte en una suerte de operación que sintetiza el tiempo y enmascara la voz de quien lo enuncia. Paradojalmente, el vínculo poético de lenguaje e historia nos pone ante la inactualidad de las circunstancias que sucedieron como presente, las cuales devienen, por su naturaleza situacional, en hechos que se alude, acciones consumadas, referencias a signos culturales, que desafían su comprensión plena al lector, operando allí en gran medida la "ironía intertextual" de la cual nos habla Umberto Eco'. Así, recordamos la poética de los "cantos" de Ezra Pound por ejemplo, con la carga literaria que eso conlleva, y su proyección en parte de

Ver de Umberto Eco "Ironía intertextual y niveles de lectura", en Sobre literatura (2005), Barcelona: Random House. 
la obra de T.S. Eliot; desde otras estéticas, aparece el tono "cotidiano" de Jacques Prevert, la Ilamada poesía contracultural de Allen Ginsberg y el movimiento beatnik. En Latinoamérica, ese recoger la historia y la contingencia que la enmarca se constituye ya desde José Hernández, se hace presente en la negritud de Aimé Césire, la propuesta de la "época social americana" de Pablo de Rokha, la escritura programática de Pablo Neruda, el "exteriorismo" de Ernesto Cardenal.

Para interés de este trabajo, si nos situamos en el panorama poético chileno de la segunda mitad del siglo XX, también es posible constatar la presencia de una poesía en la cual ese registro de la historia y la sensibilidad colectiva se ofrece como un rasgo de las prácticas de escritura, que por cierto está ligada a una identidad lírica de quienes la realizan: Enrique Lihn (Paseo Ahumada), Jaime Quezada (Huerfanías), Diego Maquieira (Los sea harrier), Juan Pablo Riveros (De la tierra sin fuegos), Raúl Zurita (Anteparaíso), Rodrigo Lira (Proyecto de obras completas), Carmen Berenguer (La gran hablada). Según puede verse, agregamos, esa praxis poética excede el marco generacional, no obstante es posible distinguir entre los escritores, naturalmente, una experiencia distinta ante la contingencia histórica, tanto por cuestiones biográficas, culturales y por cierto políticas.

A ese grupo de poetas agregamos el nombre de Tomás Harris, cuya obra llama nuestra atención dado que experimenta con formas de escritura que evocan el registro épico, que en definitiva le ha dado un fuerte rasgo unitario a su producción. No obstante ese juicio previo, la singularidad creativa de sus libros es reconocible por su estrategia de asociar, sincrónicamente, la presencia de elementos históricos, culturales y discursivos de temporalidades distintas, de modo que hay diversas instancias de realidad y formas textuales que convergen en su "poética de ficcionalización". Pensamos en Zonas de peligro (1985), Diario de navegación (1986), más fuertemente en Cipango (1992), Ítaca (2001). Luego en Tridente (2005), más cerca en fecha su libro Lobo (2007).

En este artículo hablaremos particularmente de su libro Crónicas maravillosas (Santiago: Editorial Usach, 1997), con el cual obtuviera el Premio Casa de las Américas el año 1996. Las razones de esta elección se apoyan en la estética que emerge del texto, además de nuestro interés en explorar aspectos que pueden ser problematizados y aportar en una dimensión que los estudios críticos, pensamos, aluden lateralmente. Desde nuestra lectura, y considerando la forma escritural asumida por Tomás Harris, nos preocupa en específico en las Crónicas maravillosas la actualización de una "voz" poética, en el cruce de los tiempos y de sus referentes culturales, luego la traslación imaginaria de un sujeto que devela rupturas y ensambles de una realidad que se recibe como 
extraña y situada multívocamente. Esa traslación entonces se plasma en un (des)encuentro con la historia, una voz que desdobla el texto y su propia identidad, operando en sus cambios de perspectiva y de tiempos la ficcionalización del personaje poético, el cual asume las tensiones que implican la negación o el agotamiento de su propia existencia.

\section{Nuestro problema en la poética de Harris}

En función de lo antes enunciado, la premisa de nuestro trabajo consiste en afirmar que las Crónicas maravillosas muestran a un sujeto lírico que se translocaliza cuya función es generar un efecto poético, de modo que surge una sobrelectura de la historia y de los signos culturales que intervienen en su narrativa. Inicialmente, la pregunta de base que nos hemos formulado refiere a qué efecto genera esa sobrelectura y cruce de formas textuales. También nos parece coherente interrogarse respecto de qué nos propone ese sujeto que se mueve imaginariamente en la historia e interacciona con sujetos de ficción.

Anticipándonos al desarrollo, vemos que allí se rompe el principio verosimilizador de la épica, para gestar una metaforización de las formas culturales y del sujeto que las inscribe en su movilidad. Al respecto, Harris dice al comenzar el libro que "El sentido de la Épica proviene del Epos, la Empresa. Pero no hay empresa sin Agon, sin Agonía. El Héroe no es un Héroe si no nace del estado de Agonía. Sin Agonía, acuérdate de Santana, Abraxas, cuando comenzabas a empollar tus más frágiles sueños ya destrozados, el pájaro no rompe el cascarón" (Harris, 1997:17). Con esto cobra validez una parte esencial de las afirmaciones sobre el desdoblamiento en la enunciación y el tono "interior" de una épica que asume su fracaso.

Según se deduce en esta presentación, abordar las Crónicas maravillosas supone, desde un punto de vista metodológico, establecer nexos y redes de sentido; en razón de ello es ineludible vincular el análisis con la Teoría de la recepción, por lo menos en un aspecto central: el proceso de significación supone atender los componentes extrínsecos del texto, particularmente los signos culturales a que se alude y la historia en que se inscriben. Es un hecho indiscutido que el contexto variable de la historia les impone un sentido determinado, una manera de interpretarlos, de modo que su (inactual) "relectura" involucra una experiencia nueva que recupera -a veces- la impronta metafórica de su consolidación como signos. En rigor, se actualiza el pasado, el cual converge en la contemporaneidad de la memoria propiciada por la lectura.

Otro aspecto insoslayable en esa teoría es el rol del lector, que después de todo es quien articula o inserta los textos en la historia y su 
tradición discursiva. Visto como una dimensión pragmática de una obra, se entiende que constituya el factor de cambio o de modificaciones del sistema literario. Paradójicamente, en la "Nota aclaratoria" de Crónicas maravillosas Harris expresa: "Este libro es producto de un largo y extenuante acto fallido: la desmesurada idea de escribir prescindiendo del lector; es decir, dejando divagar el deseo en asociaciones arbitrarias y fantásticas, entremezclándolas con un sentimiento de agon creciente, por la angustia de ciertas preguntas sobre mi Yo que habían quedado irremediablemente sin respuestas" (1997: 13).

Si Barthes escribió acerca de la "tachadura" del narrador y "la muerte del autor" (El susurro del lenguaje), vemos que la aspiración de Harris se sostiene en la utopía de "tachar" la lectura, la "muerte del lector", en extremo, la posibilidad de componer un libro que se sostenga no más que en el lenguaje, donde los signos y el libro mismo estarían vacíos de recepción. Es claro que sabemos de su intento fallido, no obstante cumple con acierto un desafío, en términos de crear un espacio poético propio, basado en la referencialidad, las transformaciones textuales, un sujeto lírico que (di)vaga con la historia y con la muerte. Siguiendo a Lubomir Doležel, su lectura implica asumir la "transducción literaria" del texto, considerando que dialoga con una tradición poética, "la intertextualidad, la influencia y transferencia intercultural". Las actividades de transducción -agrega Doležel-, "incluyen la incorporación de un texto literario (o de algunas partes) en otro texto, las transformaciones de un género (novela en teatro, cine, libreto, etc.), traducción a lenguas extranjeras, crítica literaria, teoría e historia literarias, formación literaria y otras (Doležel, 1997: 231-232). Harris hace transducción en su poesía y en los (sus) lectores opera el mismo principio.

Nuestro trabajo entonces es un intento de "transducción", que se sostiene en seguir algunas lecturas sobre Harris, los rasgos que constituyen su crónica maravillosa y el efecto que genera su poética de ficcionalización, al sobrearticular los tiempos y signos con un sujeto que se mueve en los espacios de lenguaje.

\section{Líneas y tramas de contexto: poesía (NN) chilena de los 80}

La producción literaria tiene de modo inevitable un ámbito mayor de pertenencia, que podemos fijar en el contexto histórico-cultural que se expresa y la tradición con la que dialoga. En este apartado consideramos a lo menos un par de esas líneas o "eslabones de sentido" (Doležel), apoyándonos en el juicio de estudiosos chilenos que han contribuido a 
interpretar la trayectoria poética chilena de fines del siglo XX, un espacio en el cual se sitúa la escritura de Harris.

De hecho, todo posible límite se inscribe en un momento en que la poesía chilena se hace de relecturas de su tradición, reconociéndose su carácter plural; sin embargo, ese panorama se complejiza por la fractura de nuestra sociedad el año 1973, de modo que esa pluralidad puede ser leída también como hererogenidad, evidenciada en las direcciones múltiples y paradojales que tuvo; en esas "zonas del dolor", ocurrió que "La poesía, la literatura, asumen frente a los discursos políticos, periodísticos y oficiales, roles de sustitución, llenando el vacío discursivo de la disidencia y la crítica. La poesía suple la ausencia verbal, sustituye los discursos clausurados, combatiendo la mudez, a la que han sido condenados por un discurso hegemónico, los modos de decir tradicionales de una sociedad" (Alonso y otros: 1989: 36).

Un trazado esclarecedor sobre el tema marcó Jaime Giordano en su trabajo "Poesía chilena actual: ficción e historia" (1987), quien explica el fondo que poseen las poéticas de ese entonces, las cuales exceden el ámbito meramente literario, pues tuvieron "el carácter de resistencia cultural". Es así como logra reconocer en los textos y autores de su estudio rasgos específicos que particularizan su escritura: pluralización del sujeto lírico, formulación de personajes, uso del discurso ajeno o atribuido, autoficcionalización. Pues bien, él asimila precisamente a Harris y su Diario de navegación entre los poetas cuya estrategia tiene como soporte la "pluralización del sujeto lírico", adscribiendo también a Diego Maquieira, Natasha Valdés, Edgardo Jiménez. Aun cuando no refiere a modelos o bien a una determinada tradición, reconocemos en esta variable de análisis un vínculo con T. S. Eliot, a lo menos con la Tierra baldía, libro en donde potenció al máximo las posibilidades de la voz poética múltiple, la "polifonía", que pone a su vez el problema de capturar la enunciación y la ubicuidad del sujeto lírico.

A nuestro juicio, si bien las variables señaladas por Giordano en su estudio caracterizan y modelan ajustadamente el periodo, el problema que vemos en ello estriba en que Harris muestra más de uno de esos componentes e incluso se sobreponen o articulan dentro de un mismo texto, en consecuencia, su lectura o análisis merece ser ampliada, o debiera haber considerado una mirada, si no distinta, a lo menos más integradora.

Una importante propuesta ordenadora ha hecho también el profesor Iván Carrasco en la Revista Chilena de Literatura № 33 (1989), esta vez focalizando su perspectiva en las direcciones poéticas del periodo 1977-1987. En su análisis, y basándose en la constatación del complejo 
panorama de nuestra poesía, llega a decir que esta se encuentra signada por la "diversidad y la heterogeneidad" (32); el criterio para establecer el año que inicia ese nuevo momento está determinado por la "ruptura de la parálisis reiterativa" de los años anteriores, evidenciada en emergencia de diversas y numerosas publicaciones de libros, junto a la actividad de grupos en distintos puntos de la geografía chilena. La ruptura a la cual alude supone el distanciamiento hacia Mistral, Huidobro, Neruda y por cierto Parra, de quien creemos difícilmente se pueden marcar diferencias radicales.

Desde ese fondo plural, llega a establecer las "tendencias" de mayor fuerza y que agrupan a poetas de estéticas específicas: neovanguardia, religioso-apocalíptica, testimonial, etnocultural. Se sabe, a esta altura del avance en los estudios literarios, lo arriesgado que resulta formular categorizaciones; en este caso, y lejos de menoscabar el significativo aporte del artículo, vemos uno problema que es necesario enunciar: las publicaciones de poesía que él menciona ${ }^{2}$, tienen un carácter transgeneracional, dicho en otras palabras, hubo libros de distintas promociones para el mismo momento de ruptura, de manera que se trató más bien de una respuesta o reacción (contra)cultural a un contexto de crisis, por otra parte, si hay algo que los mismos escritores testimonian es el trauma de la ruptura en la tradición poética, generada por la imposición de un régimen político dictatorial que determinó la distancia y el contacto entre los escritores, debidas al exilio exterior e interior, luego, ese proceso de quiebre obedeció, antes que a un fenómeno artístico, a las condiciones históricas vividas en Chile. La paradoja es que de todos modos hubo abundancia de publicaciones autoeditadas o impulsadas ya sea por "colectivos" o editoriales alternativas, un fenómeno que podemos vincular a la necesidad de romper el silenciamiento, además de mostrar un respuesta a la contingencia histórica.

Ahora bien; si nos ubicamos en la clasificación de tendencias al interior de la poesía, observamos un "pie forzado" al asociar el nombre de Tomás Harris con la tendencia etnocultural, sólo explicable por el modo de conceptualizarla, esto es, un poema "puesto en boca de un sujeto (autorial y/o hablante) que se presenta como cronista o investigador de ciertas zonas del país donde la problemática interétnica o intercultural se revela particularmente relevante" (Carrasco, 1989: 42), manifiesta en problemas sociales o el exterminio; así entonces, Harris aparece en paralelo con Clemente Riedeman y Juan Pablo Riveros con su libro De la tierra sin fuegos (1986); este es un criterio de pertenencia que luego

Por ejemplo, Astrolabio, de Jaime Quezada; Lobos y ovejas, Mester de bastardía, de Manuel Silva Acevedo; Arte de morir, Óscar Hahn; La nueva novela, de Juan Luis Martínez; Recurso de amparo, de Jorge Torres; Las musas desvaídas, escrito por Carlos Trujillo. 
reiterará Andrés Morales en su ponencia del año 2000 "La poesía de la generación de los 80: valoración de fin de siglo".

Sí es más evidente, como lo hace notar Soledad Bianchi (1990), que Harris se inscribe en la poesía del sur de Chile (pensamos en Alexis Figueroa, Carlos Decap, Carlos Cociña, Clemente Riedemann, Carlos Trujillo), próxima "a una vertiente experimental". En su artículo "Reiterar la forma de lo inasible. Una mirada a la poesía de Tomás Harris" (Mapocho, № 41, 1997), dice a propósito de Zonas de peligro, que leer el manuscrito significó para ella "descubrir una de las construcciones poéticas más interesantes y novedosas de la literatura producida con posterioridad al golpe de estado, donde se encontraba uno fuerza poco frecuente en los escritos de esos años que no siempre sabían conciliar la violencia, que muchos aludían, con un lenguaje que la expresara no sólo en su vocabulario" (225). En ese mismo trabajo, llega al convencimiento de que es una poesía que obedece a un proyecto, cuya completación se daría en Cipango, de manera que advierte (advertimos) un espacio poético singular, con textos que se entremezclan temáticamente, remiten a figuras emblemáticas en la historia del continente, traumas sociales, y que alcanzan, a pesar de ello, su propia autonomía de lectura como poemas.

Un foco distinto vemos en el artículo de Javier Campos "Tomás Harris y la cultura de la imagen. Algunas reflexiones sobre poesía chilena de los 80" (Cuadernos Hispanoamericanos № 543, 1995). Lo importante en este caso radica en que, situando su contexto generacional, hay un desarrollo explícito acerca del trabajo de Harris con la referencia a los códigos de la imagen. De hecho, cree que su poesía "se va construyendo más que nunca en la lectura de la «cultura de la imagen» que algunos poetas chilenos a partir de la década mencionada vienen haciendo cada vez más del cine, los medios visuales de alcance masivo, la fotografía, la pintura, la publicidad comercial nacional o transnacional, así como la nueva y alta tecnología que reinventa la belleza en híbridas, nuevas y sofisticadas imágenes" (135). El punto de interés en este caso radica en que lleva a considerar el nexo entre literatura y los registros visuales, que más allá de su eventual cita, refieren a una situación cultural determinada, de modo que el sentido crítico, el encuentro con las crisis de la sociedad actual, encuentran en el texto un modo nuevo de potenciarlo.

Un sentido más abarcador sobre Harris muestra Grínor Rojo en la nota prologal a la segunda edición de Cipango (1996), en tanto percibe muy claramente en el oficio poético un proyecto, "el poder de la visión" de un hablante situado ante el desgarrador panorama de la sociedad moderna. El crítico realiza un acertado vínculo entre la estrategia discursiva de $\mathrm{Ha}$ rris, esto es, su opción por el poema extenso y de orden narrativo que le permite abrir diversos espacios, con Gabriela Mistral y su Poema de Chile, o 
el "modelo" que proveniente de Canto General de Neruda. Esta referencia obedece a que cuando escribe sobre las Crónicas maravillosas (Mapocho № 44, 1998) menciona que estas se abren con una "metapoética", para luego continuar con un "programa de lectura", en tanto se advierte un supuesto al lector, una guía a seguir, en otras palabras, según veremos, las reglas en el juego de la lectura. Por cierto, esta entrada de orden teórico ahonda luego en el diseño poético de Harris, sin embargo, hacemos notar esa dimensión en la medida que apoya la idea de una continuidad o coherencia con su propio discurso, adicionalmente, pone en duda el eventual proceso de ruptura planteado por Iván Carrasco.

\section{De la crónica y lo maravilloso}

En términos amplios, se entiende que la crónica asume la construcción del presente como testimonio y su declarada permanencia en la palabra escrita para la memoria, el respaldo inequívoco de un tiempo que funda y que intenta validarse mediante un relato que oficializa el acontecer; es inevitable entonces que su lectura nos ponga ante un presente-pasado que se actualiza y traspasa al lector, construyendo un verosímil para la imaginación, donde la palabra se funde con la realidad factual del ahora, aunque su lectura sea diferida o se potencie y actualice de modo cierto en el futuro.

La crónica en la historia, en especial aquella que particulariza un modo de referir discursivamente al nuevo mundo (América), obedece a una demanda que quiere oficializar el registro de su dominio, de paso, en gran medida esa misma escritura terminará dando los atributos el estatuto genérico de una forma escritural. Cualquiera sea el caso, al igual que en otras textualizaciones, en ella se asume que el sujeto que escribe está comprometido con su propio discurso, dicho de otro modo, termina por coincidir o correlacionar el sujeto de enunciación y el autor empírico, donde ese hecho comunicativo sobreentiende la presencia imaginaria de su eventual receptor, la autoridad del Rey, quien será en definitiva el que reconozca su valor de documento oficial; él sella el rango de verdad a la conquista y las hazañas que la explican.

Ante la lectura de esa crónica, se activa la creencia en su carácter de genuino, la imposibilidad del engaño de un discurso que encuentra en la narración la forma ideal para sostener el espacio que se nombra desde la propia vivencia del cronista; sin embargo, aun cuando sea "testigo de vistas", en su proceso descriptivo selecciona de su privilegiada experiencia los elementos que componen un espacio, donde al lector sólo le cabe imaginar también la retórica de una opsis ajena; hay allí un tiempo narrado que se presentiza y condensa lo vivido al evocarlo. 
Por ello, si al escribir opera un criterio para seleccionar desde la memoria, en la crónica encontramos después de todo una modo de invención, en que surge la capacidad de escritura y la conciencia individual de un hecho colectivo, los avatares del impacto cultural y el cumplimiento del guerrero que consuma una misión ${ }^{3}$, que en ocasiones suele tener el interés de probar los (sus) méritos ante la autoridad, anteponiendo en su texto la duda de otros relatos y que son ajenos al propio. En definitiva, si hay un determinado espacio, desplazamientos en la geografía, el enfrentamiento heroico en una empresa sobrehumana, la formalización textual de la crónica hace emerger el tono épico y el sustrato mitificador de las propias acciones donde hay luchas y derrotas transitorias que culminan en el vencimiento, la honra, la sumisión del otro.

Un aspecto gravitante en Crónicas maravillosas parte entonces del nombre que da título al libro, de hecho, no hace sino predisponer de modo ilusorio al lector que el texto mostrará episodios reales que han merecido registrarse como crónica. Sin embargo, la verdad es que su textualización se constituye mediante variables de escritura que alteran y perturban sus rasgos: primero, hay una transformación discursiva o genérica, en tanto la experiencia se codifica principalmente en verso; luego, y en simultáneo, vemos que su atributo básico de verosímil-real se desplaza de tal eje, asumiendo la calidad de maravillosa, un mundo de lo posible sólo realizable en su propia constitución de lenguaje, cercana a los términos propuestos por Roger Caillois (Zvetan Todorov también), cuando habla de la literatura maravillosa y fantástica: el primer mundo se añade al real "sin atentar contra él ni destruir su coherencia. Lo fantástico, al contrario, manifiesta un escándalo, una rajadura, una irrupción insólita, casi insoportable en el mundo real" (Caillois, 1970: 10).

Las Crónicas maravillosas se inician como un "relato" de lo imposible y un desafío al lector, que al igual que advirtiera Rojo, se corresponde con un programa de lectura, una poética de la interpretación: el supuesto de que el hablante se llama Antonius Block y que sueña un juego de ajedrez con la muerte: "Supongamos que me llamo Antonius Block/y que sueño/ que juego ajedrez con la muerte, en un hospital, frente al/mar, /a cualquier mar de los 7 que hay en el orbe" [...] "Supongamos que me llamo Antonius Block y que sueño/que juego ajedrez con la muerte, /al regreso de la cruzadas de mi Historia Personal de la/Muerte/en un hospital, frente al mar, /cualquier mar" (Zumbido de abejas. Introducción).

Para este tema, remitimos al estudio de Walter Mignolo "Cartas, crónicas y relaciones del descubrimiento y la conquista", en Historia de la literatura hispanoamericana (1982), de Luis Iñigo Madrigal, Tomo I, época colonial, Madrid: Cátedra, también a Beatriz Pastor (1983) Discurso narrativo de la conquista de América: mitificación y emergencia, La Habana: Casa de las Américas. 
Es decir, nos enteramos desde un comienzo que se escribe la búsqueda deliberada de un efecto onírico, un acto imaginario que se sostiene en la identidad falseada con un sujeto de existencia fílmica -otra ilusión de la imagen-, un ser inventado (Ingmar Bergman lo hizo posible), que sí jugó con la muerte. Es la evasión en el otro que me juega y se desplaza en el mundo de lo imaginario, donde el transitar en verdad alude a genuinas estaciones del sufrimiento y la pesadilla de un tiempo en el que converge la historia de una cultura traumática: "... eran mis compañeros de pieza o celda,/que a ello y no otra cosa se asemejaba el cubículo,/dos de mis mejores capitanes, /el Maestre de Campo Alonso González de Nájera/y Alvar Nuño Cabeza de Vaca, /entre los pocos que sobrevivimos a los pantanos, /la malaria y los manglares" [...] "comenzaron a aparecer/como los créditos de una película vieja/en la pantalla del Cine Ducal; Tebas, Guernica, Cipango/y de esta manera continuaban y continuaban, /Zaire, Ruanda, Tenochtitlán, /Hiroshima, Belfast, Croacia, Tebas ..." (Zumbido de abejas. Introducción).

Desde ese prisma, resulta esperable entonces que emerja en el texto un mundo de referentes en que se rompen los códigos de realidad, un mundo en que se alteran las convenciones lógicas y perceptuales, el orden establecido que separa los espacios de representación, lo cual propicia el encuentro con un mundo literario que genera a sorpresa o extrañeza, moviéndose extratextualmente hacia diversos signos culturales y épocas. En este sentido, constituye un libro asociable con una forma escritural que hemos conocido en las páginas de Colón y Pigafetta por ejemplo, quienes construyen una "América imaginaria (Rojas Mix), que se traspasa a otros espacios geográficos y que marca un horizonte de expectativas culturales.

Esto es lo que hemos Ilamado "asincronías" de la escritura y la lectura; aquí aparece un problema complejo para el pacto de lectura, en tanto Harris apuesta a que el lector entienda esa asincronía, donde confluyen formas y signos culturales provenientes del cine, la literatura misma, la pintura, la música, lugares, entre otros, y que es necesario interpretar, junto con asumir la transformación genérica de la crónica. En la ficcionalización de la historia se hace converger entonces la pluralidad de voces y su textualización poética en formas que vulneran al canon genérico (pensamos en la crónica, el diario de viaje, la bitácora), de modo que la asincronía de fenómenos históricos y culturales, es articulada con el uso de un discurso atribuido, que transforma su escritura original (prosa) al verso. El problema que se observa allí es el sentido que tiene la navegación y los viajes aparentes, esos desplazamientos que la lectura (a)crítica habitualmente adscribe a un simple traslado geográfico, inadvirtiéndose la asimilación del tono de la crónica, tratada en un formato no prosaico (el verso), los cambios o asimilación de los nombres y lugares: Antonius Block convertido en almirante, Laura Palmer (Twins Peaks de David Lynch), asi- 
milada a la Doncella y la consecuente película de Bergman, la joven Ofelia (Hamlet), que se ahoga, aunque en el Biobío; Tebas, Cádiz, desplazadas a Chile y la ciudad de Concepción. En una primera aproximación, se diría que simplemente remiten a una conciencia onírica, asociaciones secretas de una mente alucinada, que termina entregando, antes que espacios maravillosos, el pavor de un mundo fantástico ante la inevitabilidad del desastre y que hace brillar luces de neón en el bosque.

Así, las Crónicas se transforman en un texto heterogéneo que constituye un collage verbal dinamizado en el proceso de lectura, cuyos "puntos de fuga" abren canales no verbales de significación; es el peso de la imagen entendida como signo, o un conjunto de imágenes en realidad, sintetizadas en la capacidad de símbolo cultural. Bergman y Lynch son más un nombre, luego, los factores que los articulan en el texto sin duda convergen en otra narración, el metasigno crítico y la reflexión filosófica.

Por ello, la presencia de una estrategia escritural basada en la sintaxis anacrónica de los hechos constituye no sólo un procedimiento, sino que permite mostrar(nos) la imagen fracturada de un mundo, que muestra en su reverso la inabarcabilidad de su plena comprensión.

De ahí tal vez el que ese Antonius Block que sueña jugar una partida de ajedrez con la muerte, quiera recuperar en su recorrido imaginario las circunstancias de su delirio, la dispersión de los tiempo con la presencia ubicua de la muerte. En la época contemporánea, la partida se transformará en un juego electrónico, de modo que la destreza del hablante le permite pasar a otra etapa: "Ahí, en el pleno centro maliluminado/de la maldita pantalla de juego de video/al fondo de un callejón adoquinado/ de la gótica malparida ciudad ya dicha/con una fogata falsa alumbrando el relato/apareció magra la instrucción en sordina/pidiendo la piedad prohibida por los postes/del medieval alumbrado eléctrico ..." (El caballero y la muerte se inclinan sobre el tablero de video)

Son las batallas de ficción en una cultura (la nuestra), donde la muerte se construye en el derroche tecnológico y el heroísmo propiciado por juegos bélicos virtuales, la muerte aséptica, limpia, la de los botones y la hipnotizante pantalla fría, como la muerte.

\section{Alteridad y sobrearticulaciones del discurso}

Las diversas instancias que transcurren en el desplazamiento de Antonuis Block, tienen como fondo el encuentro con la muerte; sin 
embargo, hay otra variable en su narrativa, pues instala la posición de la voz múltiple materializada en un discurso de la alteridad, de modo que emerge una compleja sobrearticulación del sujeto que enuncia. En otras palabras, los poemas de Harris ponen al lector ante una estrategia donde el hablante se multiplica y asume formas e identidades discursivas que complejizan la trama de la lectura.

En tal sentido, las Crónicas se despliegan en espacios y tropismos imaginarios con una temporalidad que se transgrede, cuya integración se ofrece por una voz que adopta la personalidad de un sujeto que asume la inevitabilidad de la muerte, pero además con un "telón de fondo" que devela las tensiones de una cultura que se transforma y enmascara la épica anticipada de su fractura y el propio olvido: "Yo soy Antonius Block, almirante de esta misión/¿Cuál era mi misión?/¿Refundar Tebas, la de las 7 puertas y su desavarío,/reconstruir el Almirante Benbow, /con todas sus vespacianas, pipeño bigoteado, indias de/bronce, /con sus cascadas impensables de asco áureo-negro, placer y/circular ardor ..." (Yo soy el Almirante Antonius Block quien les habla).

El límite: Antonius Block, almirante de una empresa guerrera y que juega ajedrez con la muerte, se convierte en un ser existencial que se pregunta por su identidad: "iNo sé quién soy!/¿Un robot programado para obedecer a la orden de Dios?/¿Quién soy bajo el yelmo?". /Las interrogantes atormentaban mi mente vaciada. /No soy nada/No soy nada/No soy nada" (Antonius Block, almirante de esta misión, bajo los efectos del gas del miedo, pregunta por su condición).

Entonces, ocurre que allí en ese no-lugar Antonius Block se encuentra junto a dos de sus mejores capitanes, el Maestre de Campo Alonso González de Nájera y Alvar Nuño Cabeza de Vaca sobrevivientes de una expedición; luego comienza a explorar en el delirio, acalambrado por la apomorfina que le inoculaba nada menos que Ronald Silver el Largo, o John Silver el Largo, el pirata perteneciente a la flota del capitán Flint de La Isla del tesoro, quien deviene de personaje literario a una suerte de asistente torturador en el hospital donde yace Block. Desde ahí emprende el viaje junto a su tripulación para llegar más tarde a una ciudad sumergida, enclavada en una zona de Sudamérica. Extrañamente, desde su condición de personaje ficticio, se interroga ante lo que observa: “¿Dónde está lo real?, me preguntaba yo, Antonius Block, /Almirante de esta misión, /frente a esta especie de costa ojival y dorada. /Junto a mí, Alvar Nuño Cabeza de Vaca y González de/Nájera. /Tras nuestros 3 cuerpos irguiéndose deshilachados, /que más parecían enormes velas negras que cuerpos, /se mecían convulsionados/la Juana-Guy y el S.S. ACHAB" (¿Dónde está lo real?). 
Allí comienza a recordar el cofre del barco con los discos de Coltrane, Parker, Holliday, Hendrix, "el mártir de las 60 esperanzas". Cuando desciende en la arena, ocurre un hecho clave, la nao espacial Nostromo -esa nave ficticia que aparece en la película "Alien"-, cruzaba el cielo "salpicando carne y sangre". Cabe imaginarse aquí la forma de componer una escena poética que se reitera, asimismo, el desafío para decodificar la connotación cultural de las citas y referencias.

Puede pensarse entonces en un sujeto perdido que ignora u olvida su condición, quien mientras se desplaza observa y alude, sincrónicamente, a cuadros de Munch, habla de Kirilov y Raskolnikov, Nosferatu, John Silver el Largo, Otto Dix, Ofelia que yace en el Biobío, Gaspar Ilóm el guerrillero, Tebas, que es igual a Concepción y Chichen Itzá, La fuente de la doncella confundida con Laura Palmer, la gran masacre de Texas, la nave Nostromo que lo conduce y que evoca la saga del Alien; también la novela de Joseph Conrad, quien funda la República de Costaguana en un inventado y fantasioso territorio sudamericano, donde se mezclan lo patético con lo ideal, el exotismo y la brutalidad de un mundo en que todo esfuerzo humano parece inútil.

En un cambio de perspectiva y de la voz que enuncia, se cuenta cómo "Antonius Block se internó" en sus pesadillas en suspenso; entonces, los lugares de ese recorrido por el falansterio de las abejas, se abren a múltiples salidas que se fusionan como "paisajes de infortunios", la "morfología del martirio", haciendo que esa movilidad en la historia y el sentido del viaje nos recuerde la desolación del infierno, que hace evocar a Block los cuadros fantásticos de El Bosco: "patios descubiertos que daban/a los cerros de Puerto Montt, de Talcahuano, /de la caleta de San Vicente, de Coronel, /de Valparaíso, de Coquimbo, /cerros donde se aglomeraban/las miserables casuchas de cartón piedra o zinc/de los mineros o pescadores, /con todo su fanal de hechos de sangre, /de quemaduras, de magulladuras y cicatrices en los muros ..." (El falansterio de las abejas).

Los falansterios de la historia y de la muerte, tienen como empresas heroicas la aniquilación de los Malatos (léase leprosos), aventuras crueles que luego son convertidas en las etapas de un video game que le permiten continuar la aventura: la muerte es otra víctima del progreso cultural, que ya no puede desafiar ni juega ajedrez ante el tablero, sino que adopta juegos de guerra electrónicos, observándose en la pantalla de video.

Pero leemos también el diálogo con la muerte, la cual experimenta también los cambios de la vida moderna y responde con un típico chilenismo: "¿Tú juegas ajedrez, no es cierto?/¿Qué te hace suponer tamaña huevada?/Lo he visto en los cuadros y lo he oído en infinidad de/canciones y leyendas. /Eso era antes, /cuando había cuadros y canciones y 
leyendas. /¿Qué juegas ahora?/Juegos de Guerra/en el video game de los dominios" (El desafío).

Como sujeto medieval, Antonius, el almirante que es testigo a su vez de la ejecución de una muchacha por brujería, cuya "boca se abre como el grito de Munch", le pregunta acerca del conocimiento carnal con el demonio, entonces la acusada le interroga del porqué de su insistencia en preguntar por él, y le responde: "Quiero encontrarlo yo también. /Quiero preguntarle sobre Dios. Si existe, él debe saber más /que nadie sobre Dios" (La bruja III).

Esos diálogos y escenas encuentran nuevas voces que narran; esto en gran medida delimita y marca la estructura interna de las Crónicas; es "A la hora de la pleamar", cuando Antonius Block da la orden para desembarcar a la tripulación a la "playa de Tebas, la de las 7 puertas electrocutadas", donde inician la campaña contra los 7 Malatos, acompañado por Alvar Nuño Cabeza de Vaca y el Mariscal de Campo González de Nájera. Entonces leemos, ficticiamente, el discurso en primera persona de González de Nájera, fragmentos de la crónica que dejara Cabeza de Vaca, o el testimonio narrado de su presencia en las palabras de Block, como la locura del primero, quien "comenzó una muerte inmisericorde, /enloquecido por los vahos del Almirante Benbow de Tebas" (De cómo enloqueció el Mariscal de Campo González Nájera).

Así pues, el desarrollo del libro nos muestra niveles de realidad de lo posible, con tiempos que los entrecruzan, convirtiendo así las referencias culturales en utopías de lo imposible: "Por la carretera pasaban los automóviles nocturnos rayando el paisaje con sus fríos faros. Antonius Block reconoció la planta y recordó con estremecimiento algo que había leído sobre ella en La inteligencia de las flores de Maurice Maeterlink" (Desechos alegóricos dictados por la noche).

Por otra parte, el lenguaje y sus referentes muestran la (a)historicidad de las circunstancias que se hacen formas trágicas o mascaradas, otros momentos son registros de parodia y de la sospecha irónica que niega la posibilidad de la certeza, para hacernos cómplices en la eventual lectura de sus múltiples códigos y el sustrato desesperanzado ante la pérdida de los ejes culturales que les dan pleno sentido. Ante la evidencia de propia perdición, Antonius Block expresa: "Mi destino me lo mamaré solito, /fétido, borracho sin alma, /con la peste de las ganas, /con la peste de los sueños/que empollarán cascadas de/ratas armónicas que se desparramarán/por los corredores del cerebro de Torquemada" (Del destino de Antonius Block, almirante de esta misión, referido por él mismo").

Desde otro ángulo, el libro muestra en su narrativa un giro en la 
representación de ese espacio poético. Su efecto es que, antes que maravillas, encontramos la presencia de marcas y experiencias que desde la ficción poética, conducen hacia los límites de lo fantástico, con un sujeto de discurso que experimenta la épica de una derrota: "Nadie pasa de la etapa donde aguarda el Arcano Mayor./(¿La Caída, El Colgado?)/Y ya no quedan fichas de oro los bolsillos/para introducirle a la máquina de video que se pudre en/un sórdido rincón como un infernal rinoceronte en latencia" (The end). Sin embargo, ese delirio experimentando desde la butaca (Epílogo), muestra cómo los "personaje que fueron convocados/por la ficción" se alejan hacia la noche; en un último juego literario, también permanece la esperanza pues "uno sobrevivió a la catástrofe", según la cita de Melville puesta al final del libro.

\section{Conclusiones}

En coherencia con nuestro planteamiento inicial, vemos que los aciertos de escritura realizados por Tomás Harris, inducen a reafirmar que su estudio demanda que se opere con un discurso analítico distinto, en tanto decodificar su sentido excede la suficiencia de los recursos que lo componen, situándose así a contrapelo de aquellas concepciones que cierran el texto en sus componentes formales; lejos de asumir que tal fenómeno constituya un problema nuevo, (nos) resulta evidente en tal sentido que su lectura exige (re)poner la aproximación crítica al texto poético en diálogo con otros signos culturales y narrativas, las significaciones que aportan los medios en el imaginario y con nuestra historia cultural, que no es ajena a los procesos de modernización y (males) de la globalización.

Dado el modo en que construye la mirada personal de Antonius Block, su resultado (significación) son las visiones acerca de una respuesta ante la complejidad propia y colectiva de la existencia, la comprensión de la historicidad y de la transitoriedad propia en ese continuum del cual rescata el trauma del sueño y el viaje imaginario al cual se nos invitó. Vemos entonces en ello que la experimentación con la movilidad de la voz poética, las alusiones históricas y a la cultura, entregan a las Crónicas un carácter (anti)épico, sustentado en ese héroe que asume su destino trágico y la ruptura del orden que termina en el absurdo. Si esto es una parte de su sentido, habremos pasado una fase del juego. En ese mismo concepto, ese sujeto de escritura que instala la voz de diversos cronistas -testigos privilegiados-, al hacer contemporáneas circunstancias que han ocurrido en marcos temporales y culturales distintos, sobrearticula los sentidos que parecen ser una suerte de alucinación en que se pierden los referentes y que dan forma a una conciencia delirante, cuya muestra encontramos en la mejor literatura surrealista o de arte fantástico. 
Poéticamente, desde el lenguaje mismo se entiende, la "transducción" muestra niveles expresivos que recodifican prácticas culturales no lingüísticas -imágenes del cine, música, pintura-, formando así un texto múltiple donde el sujeto tiende a desplazarse, un collage verbal que se dinamiza con la lectura; estrategias de composición en que se emplean verso y prosa, un rasgo que elimina o integra las posibilidades del lenguaje, rompiendo la convención genérica del texto lírico y la voz autoral es suplantada. En parte al menos, esto puede ser vinculado al proyecto original que planteara Harris, sin embargo, siguiendo a Blanchot, pudo advertir, pensamos, que "cuando el sujeto se torna ausencia, la ausencia de sujeto o el morir como sujeto subvierte toda la frase de la existencia, saca el tiempo de su orden, abre la vida a la pasividad, exponiéndolo a lo desconocido de la amistad que nunca se declara" (Blanchot, 1990: 32).

Por ello, la referencia poético-ficcional, en otras palabras, ese mundo de lo posible literariamente hablando, si bien es materializada mediante el soporte de múltiples referencias culturales y la multiplicidad de voces, estas asumen textualmente una función connotadora de su sentido original, son signos de otros signos: la cultura deviene una variable en la metafísica del dolor y la pesadumbre: Block/Harris, la sociedad de la muerte. En resumen, la poética de ficcionalización funciona en este caso como un soporte que entrega, además de intensidad poética al texto, la imagen fracturada de la realidad que se alude y construye

En tal sentido, sin ánimo de reduccionismos, las Crónicas maravillosas muestran cómo en Chile se pasó de la poesía emergente a la diáspora absoluta; la subjetivación de la cual se habló pasó a convertirse en testimonio del dolor, las páginas parodian el discurso para superar el silencio; el sujeto lírico se pierde en la historia y responde con las voces perdidas de la utopía que nos diera origen e identidad.

\section{Bibliografía}

\subsection{Corpus del autor}

Harris, Tomás (1992): $\quad$ Cipango, Santiago: Documentas

Cipango, México: FCE. Prólogo de Grínor Rojo

Crónicas maravillosas, Santiago: Editorial Usach

\subsection{Antologías}

Alonso, María Nieves; Mestre, Juan Carlos y otros (1989):

Las plumas del colibrí. Quince años de poesía en 
Lo maravilloso y la ficcionalización del sujeto en Tomás Harris /

Dr. Jorge Ferrada Alarcón

Concepción (1973-1988), Santiago: Cesoc. Tiene estudio introductorio

Calderón, Teresa; Harris, Tomás (1999):

Veinticinco años de poesía chilena (1970-1985),

México: FCE. Prólogo de los autores

Díaz, Edwin (1991): $\quad$ Poesía chilena de hoy, Santiago: Documentas. $4^{\circ}$ edición. Prólogo de Federico Schopf

\subsection{Estudios críticos}

Bianchi, Soledad (1997): "Reiterar la forma de lo invisible", Santiago: Mapocho No 41

(1990): Poesía chilena, Santiago: Documentas

Campos, Javier (1995): “Tomás Harris y la cultura de la imagen. Algunas reflexiones sobre la poesía chilena de los 80", Madrid: Cuadernos hispanoamericanos

Carrasco, Iván (1989): "Poesía chilena de la última década", Santiago: RCHL No 33

Giordano, Jaime (1987): "Poesía chilena actual", en Dioses, antidioses, Concepción: Lar

Herrera, Juan (2005): $\quad$ "Hacia una estética de la desaparición en la poética de Tomás Harris", Concepción: Acta literaria № 30

Mac Millan, Mary (2001): $\quad$ "El porqué de la crónica: una lectura de Los 7 náufragos de Tomás Harris", Santiago: Mapocho № 49

Morales, Andrés (2000): "La poesía de la generación de los 80: valoración de fin de siglo", Santiago: Cyber humanitatis No13, Facultad de Filosofía y Humanidades, U. de Chile

Roa, Armando (2005): $\quad$ "Tomás Harris: Tridente", Santiago: Taller de letras № 37

Rojo, Grínor (1998): "Crónicas maravillosas", Santiago: Mapocho № 44

Zaldívar, María Inés (2005): "Tres miradas a Tridente de Tomás Harris", Santiago: Cuadernos de la Fundación Neruda № 57

\subsection{Fuentes teóricas}

Barthes, Roland (2002):

"La muerte del autor", "La tachadura", en EI susurro del lenguaje, Buenos Aires: Paidós

Blanchot, Maurice (1990): La escritura del desastre, Caracas: Monte Ávila 
Bloom, Harold (1986): $\quad$ "Preludio: todo tiene su precio", en Los vasos rotos, México: FCE

Caillois, Roger (1970): Imágenes, imágenes, Barcelona: Edhasa

Dolezel, Lubomir (1986): "La transducción literaria", en Historia breve de la poética, Madrid: Síntesis

Eco, Humberto (2005): "Ironía intertextual y niveles de lectura", en Sobre literatura, Barcelona: Random House

Todorov, Zvetan (1987): Introducción a la literatura fantástica, México: Premia editora 